Article

\title{
Israeli Acute Paralysis Virus Infection Leads to an Enhanced RNA Interference Response and Not Its Suppression in the Bumblebee Bombus terrestris
}

\author{
Kaat Cappelle ${ }^{1, *}$, Guy Smagghe ${ }^{1}$, Maarten Dhaenens ${ }^{2}$ and Ivan Meeus ${ }^{1, *}$ \\ 1 Department of Crop Protection, Faculty of Bioscience Engineering, Ghent University, Coupure Links 653, \\ 9000 Ghent, Belgium; guy.smagghe@ugent.be \\ 2 Department of Pharmaceutics, Faculty of Pharmaceutical Sciences, Ghent University, \\ Ottergemsesteenweg 460, 9000 Ghent, Belgium; maarten.dhaenens@ugent.be \\ * Correspondence: kaat.cappelle@ugent.be (K.C.); ivan.meeus@ugent.be (I.M.); \\ Tel.: +32-9-264-6146 (K.C. \& I.M.)
}

Academic Editor: Karyn Johnson

Received: 28 October 2016; Accepted: 13 December 2016; Published: 19 December 2016

\begin{abstract}
RNA interference (RNAi) is the primary antiviral defense system in insects and its importance for pollinator health is indisputable. In this work, we examined the effect of Israeli acute paralysis virus (IAPV) infection on the RNAi process in the bumblebee, Bombus terrestris, and whether the presence of possible functional viral suppressors could alter the potency of the host's immune response. For this, a two-fold approach was used. Through a functional RNAi assay, we observed an enhancement of the RNAi system after IAPV infection instead of its suppression, despite only minimal upregulation of the genes involved in RNAi. Besides, the presence of the proposed suppressor 1A and the predicted OrfX protein in IAPV could not be confirmed using high definition mass spectrometry. In parallel, when bumblebees were infected with cricket paralysis virus (CrPV), known to encode a suppressor of RNAi, no increase in RNAi efficiency was seen. For both viruses, pre-infection with the one virus lead to a decreased replication of the other virus, indicating a major effect of competition. These results are compelling in the context of Dicistroviridae in multi-virus/multi-host networks as the effect of a viral infection on the RNAi machinery may influence subsequent virus infections.
\end{abstract}

Keywords: Israeli acute paralysis virus; cricket paralysis virus; RNA interference (RNAi); viral suppressors of RNAi; Bombus terrestris; bee health

\section{Introduction}

No domain of life is exempt from the threat of viruses [1], which hijack the cellular metabolic pathways to produce the genomic material and proteins needed for their own replication [2]. In order to counter these attacks, organisms have developed various defense mechanisms. Whereas in mammals the antiviral response is predominately mediated through the interferon response [3-5], in plants, nematodes and arthropods, this defense is carried out mainly by the RNA interference (RNAi) pathway [6,7]. This pathway is triggered by double-stranded RNA (dsRNA), the replicative intermediate form of RNA viruses [8,9], which is recognized and cleaved by the protein Dicer-2 (Dcr-2) to produce small interfering RNAs (siRNAs). These siRNAs are loaded onto Argonaute-2 (Ago-2) within the RNA-induced silencing complex (RISC) which guides the siRNA to complementary viral RNA strands and cleaves them, thereby preventing the production of the associated viral proteins [10]. If the RNAi mechanism acts systemically, a viral sequence-specific signal can be spread to uninfected tissues, resulting in a, at least partially, protected status of these cells [11]. 
During evolution, viruses have not stood by idly while their hosts developed this RNAi defense mechanism. Viruses known to encode viral suppressors of RNAi (VSRs) have been found in plants [12] and insects [13-18]. These VSRs are often small proteins which exercise their function through various mechanisms such as dsRNA sequestering and Dcr-2 or Ago-2 binding. Within the Dicistroviridae, a family of positive single-stranded RNA viruses infecting arthropods, a 166 amino acids (AA) long protein, called 1A, has been proven to be a functional VSR in both the drosophila C virus [14] and the cricket paralysis virus (CrPV) [15]. Recently, the presence of a similar 1A protein has been suggested in another member of the Dicistroviridae, Israeli acute paralysis virus (IAPV). The proof of its functionality was based on reduced virus titers after silencing the $1 \mathrm{~A}$ region, compared to targeting the non-coding $5^{\prime}$ internal ribosome entry site (IRES) region [19], indicating the need of 1A for virulence. This method might be insufficient by itself, as 1A is a post-translation product and confounding effects like dsRNA target accessibility were not considered. Another small open reading frame (ORF), tentatively named orf X (or pog), has been predicted in IAPV and its close relatives but not in CrPV [20,21], and the presence of the resulting protein has been confirmed for IAPV in honeybees [22] but not for Solenopsis invicta virus 1 (SINV-1) [23]. As of yet, no functionality has been attributed to this putative 94 AA protein. VSRs can be very potent in the inhibition of the RNAi mechanism and therefore important immunosuppressive virulence factors. The actual virulence of a virus, defined as the relative capacity to cause damage in a host, depends on the balance between the power of the suppressor and the capacity of the RNAi mechanism of the host to limit the replication of the virus and, hence, the production of this inhibitor.

The aim of this study was to investigate to what extent IAPV can influence RNAi efficiency, and to which direction this balance will sway, in the bumblebee Bombus terrestris. This virus is known to pose an important health danger to pollinators such as honeybees and bumblebees $[24,25]$ and is a target for RNAi-based antiviral therapeutics [26]. As an extra control, CrPV, with its known VSR in Drosophila, was included. CrPV has not been reported as a problematic infection of the pollinator community and has a broad host range as it was reported to infect species within the insect orders of Heteroptera, Diptera, Lepidoptera and Hymenoptera, at least in experimental conditions [27-29]. Within the concept of virus multi-host dynamics [30], the presence of VSRs can severely impact the virus virulence in different hosts, as the immunosuppressive capacity is dependent on the host immune strategies and their sensitivity towards VSRs. Also within the same host species, VSRs can influence the virulence of co-infecting viruses [31], an important feature now that multi-virus reports in pollinators are emerging [32,33].

In order to evaluate the effect of IAPV infection on RNAi efficiency in B. terrestris, we used a dual approach. First, a proteomic analysis was performed to confirm the translation of the VSR 1A and predicted OrfX proteins using the data-independent acquisition method with high definition mass spectrometry $\left(\mathrm{HDMS}^{\mathrm{E}}\right)$. Second, the RNAi efficiency after IAPV and CrPV infection was determined. An assay was developed in which bumblebees were infected with a fixed amount of viral particles and after an incubation period injected with dsRNA targeting peptidylprolyl isomerase A (ppia), a gene known to remain stable during virus infection [34]. Silencing levels were evaluated using reverse transcription quantitative PCR (RT-qPCR), along with expression levels of the RNAi core genes, $d c r-2$ and ago-2, and the systemic RNAi genes, ninaC, egghead and sid-1 [11].

\section{Materials and Methods}

\subsection{Bumblebee Rearing and Injections}

All experiments were performed using 5-to-10 day old workers, age fixed within each experiment, collected from Bombus terrestris colonies (Biobest NV, Westerlo, Belgium). Several workers were collected from the colonies and verified to be virus-free by PCR [35]. One or two workers were collected from each colony and randomly distributed over the microcolonies for the experiments. These microcolonies were placed in an incubator at $30{ }^{\circ} \mathrm{C}, 60 \%$ relative humidity and in continuous darkness and fed with sugar water $\left(50 \% w / v\right.$, BIOGLUC $^{\circledR}$; Biobest NV) and gamma-irradiated 
pollen (Soc. Coop. Apihurdes, Pinofranqueado-Cáceres, Spain). Prior to injections with virus- or dsRNA-containing solutions, the bumblebees were anaesthetized by placing them on ice in a plastic container for $5 \mathrm{~min}$. The bumblebees were then injected through the abdominal intersegment membrane between the second and third segment using an Femtojet Microinjector (Eppendorf, Hamburg, Germany). A volume of $5 \mu \mathrm{L}$ was used for all virus solutions (and the appropriate controls), while dsRNA was injected in a volume of $20 \mu \mathrm{L}$.

\subsection{Virus Production}

IAPV was produced by injecting 160 virus-free bumblebees with 500 IAPV particles and waiting three days for the virus to amplify within the body. Then the bumblebees were crushed in $10 \mathrm{mM}$ phosphate buffer ( $\mathrm{pH} 7.0$ ) supplemented with $0.02 \%$ diethyldithiocarbamate. The resulting suspension was centrifuged for $15^{\prime}$ at $800 \times g$ and $4 \mathrm{~h}$ at $100,000 \times g\left(4{ }^{\circ} \mathrm{C}\right)$. The resulting pellet was resuspended in $6 \mathrm{~mL}$ demineralized water. Subsequent dilutions were in phosphate buffered saline (PBS). Contamination of other common bumblebee viruses such as acute bee paralysis virus $(\mathrm{ABPV}), \mathrm{Kashmir}$ bee virus (KBV), slow bee paralysis virus (SBPV), chronic bee paralysis virus (CBPV), deformed wing virus (DWV), Varroa destructor virus-1, Sacbrood virus and black queen cell virus, was determined to be less than $0.1 \%$ of the IAPV level by RT-qPCR [36] and the stock was negative for CrPV (determined by PCR).

$\mathrm{CrPV}$ was produced within the Schneider-2 (S2) cell line, which was tested to be negative for flock house virus, Drosophila melanogaster $\mathrm{X}$ virus, Drosophila melanogaster American nodavirus, Drosophila melanogaster totivirus and Drosophila melanogaster birnavirus [37]. $40 \mu \mathrm{L}$ of CrPV inoculum $\left(10^{6}\right.$ particles $\left./ \mu \mathrm{L}\right)$ was used to infect $40.10^{6} \mathrm{~S} 2$ cells and $15 \mathrm{~h}$ later the resulting viral particles were obtained by repeated freezing and thawing in a ultrafreezer $\left(-70{ }^{\circ} \mathrm{C}\right)$ and subsequently applied to $300.10^{6}$ cells. $15 \mathrm{~h}$ later the resulting viral suspension was cleared of cell debris by centrifuging twice: $15^{\prime}$ at $800 \times g$, followed by $30^{\prime}$ at $20,000 \times g$. The viral suspension was cleaned further by ultracentrifuging $2 \mathrm{~h}$, at $4{ }^{\circ} \mathrm{C}$, at $100,000 \times g$ in a $15 \%$ sucrose gradient. The pellet was collected, resuspended in PBS and tested negative for IAPV, ABPV, KBV, DWV and SBPV using PCR [35].

For both viruses, the concentration of viral particles was estimated by transmission electron microscopy (CODA-CERVA, Brussels, Belgium). Briefly, Alcian blue-treated grids were deposited on a $15 \mu \mathrm{L}$ drop of solution for $10 \mathrm{~min}$ and rinsed two times with water. Afterwards, the grids were stained for $10 \mathrm{~s}$ on a drop of $2 \%$ uranyl acetate (Agar Scientific, Stansted, UK), blotted and air-dried. The samples were imaged in bright field (BF) mode using a Tecnai Spirit TEM (FEI, Hillsboro, OR, USA) with Biotwin lens configuration operating at $120 \mathrm{kV}$. Five micrographs were recorded per sample using a $4 \mathrm{~K} \times 4 \mathrm{~K}$ CCD camera (Eagle, FEI) at a magnification of 30,000 times.

\section{3. dsRNA Synthesis}

The dsRNA was prepared using the MEGAscript RNAi Kit (Life Technologies, Carlsbad, USA) according to the manufacturer's specifications. The T7-DNA products used as dsRNA template were generated during a PCR reaction (five cycles using an annealing temperature of $55{ }^{\circ} \mathrm{C}$ followed by 25 cycles at $60^{\circ} \mathrm{C}$ ) using cDNA of bumblebee workers and the appropriate T7-primers (Table 1). For preparation of dsGFP, a linearized plasmid containing the green fluorescent protein (GFP) sequence was used as template. The dsRNA was eluted in $50 \mu \mathrm{L}$ hot nuclease-free water and after concentration measurement, stored at $-20{ }^{\circ} \mathrm{C}$. 
Table 1. Overview of the primers used in this work.

\begin{tabular}{|c|c|c|c|}
\hline Primer Name & Sequence $\left(5^{\prime}-3^{\prime}\right)$ & Length (bp) & Eff. (\%) \\
\hline IAPV_qF & CCATGCCTGGCGATTCAC & \multirow{2}{*}{203} & \multirow{2}{*}{$97-102$} \\
\hline IAPV_qR & CTGAATAATACTGTGCGTATC & & \\
\hline CrPV_qF & AAACGCAAAAACAGCGAAAC & \multirow[b]{2}{*}{110} & \multirow[b]{2}{*}{ 103-104 } \\
\hline CrPV_qR & CACATCAAGCACCAAAGCAT & & \\
\hline rpl23_q F & GGGAAAACCTGAACTTAGGAAAA & \multirow[b]{2}{*}{143} & \multirow[b]{2}{*}{$86-99$} \\
\hline rpl23_q R & ACCCTTTCATTTCTCCCTTGTTA & & \\
\hline ubi_q F & GGTATTTGGATGCCAGTGATTT & \multirow[b]{2}{*}{129} & \multirow{2}{*}{$94-96$} \\
\hline ubi_qR & ATGGGCATTTCTACCCCTTTTA & & \\
\hline ppia_qF & TCGTAATGGAGTTGAGGAGTGA & \multirow[b]{2}{*}{132} & \multirow[b]{2}{*}{$84-94$} \\
\hline ppia_qR & CTTGGCACATGAAGTTTGGAAT & & \\
\hline dcr-2_q F & TGGTCAAAACATCAAGAACAACCA & \multirow{2}{*}{211} & \multirow{2}{*}{$93-97$} \\
\hline dcr-2_qR & GATCGGGGCCATACGAACAT & & \\
\hline ago-2_q F & CCGAATGTGGACAATGCTTA & \multirow{2}{*}{181} & \multirow{2}{*}{$95-102$} \\
\hline ago-2_q R & AACGGGCAAAGGTGTGATTA & & \\
\hline sid-1_q F & CGAGCCCATCAACGGTAGAA & \multirow{2}{*}{160} & \multirow{2}{*}{$94-107$} \\
\hline sid-1_qR & CGAGCCAAATCACAAACGGA & & \\
\hline ninaC_q F & GCGAAACCATCTGGAGGATA & \multirow{2}{*}{112} & \multirow{2}{*}{$91-106$} \\
\hline ninaC_q R & ACTCTGTTAGCCGCATCGTT & & \\
\hline egghead_qF & ACCGGAGGACTTAGTTGGAA & \multirow{2}{*}{122} & \multirow{2}{*}{$93-97$} \\
\hline egghead_qR & TGCGGAAAGGAAAGAAATGT & & \\
\hline GFP_T7 F & TAATACGACTCACTATAGGGTACGGCGTGCAGTGCT & \multirow{2}{*}{495} & \multirow{2}{*}{ / } \\
\hline GFP_T7 R & TAATACGACTCACTATAGGGTGATCGCGCTTCTCG & & \\
\hline ppia_T7 F & TAATACGACTCACTATAGGGCACTGGTGGAAGGTCCATCT & \multirow[b]{2}{*}{388} & \multirow[b]{2}{*}{ T } \\
\hline ppia_T7 F & TAATACGACTCACTATAGGGAAGGGAAAATGGTGATGATTAGAA & & \\
\hline
\end{tabular}

bp, base pairs; Eff., minimal and maximal amplification efficiencies over the different experiments; IAPV, Israeli acute paralysis virus (EU436443.1); CrPV, cricket paralysis virus (KP974707.1); rpl23, 60S ribosomal protein L23 (XM_003400707.2); ubi, polyubiquitin B (XM_003402262.2); ppia, peptidylprolyl isomerase A (XM_003402218.2); dcr-2, dicer-2 (XM_012307737.1); ago-2, argonaute-2 (XM_012312881.1); sid-1, systemic RNA interference (RNAi) deficient 1-like (XM_012315164.1); ninaC, neither inactivation nor afterpotential C (XM_003393094.2); egghead, beta-1,4-mannosyltransferase egghead (XM_012321382); GFP = green fluorescent protein (M62654.1). 


\subsection{RNA Extraction, $c D N A$ Synthesis and RT-qPCR}

RNA was isolated using the RNeasy Mini Kit (Qiagen, Hilden, Germany) according to the manufacturer's instructions and treated with the Turbo DNA-free kit (Life Technologies). For cDNA synthesis, 500 ng RNA was used in each reaction, performed with the SuperScript II Reverse Transcriptase Kit (Life Technologies). The RT-qPCR reactions were performed in duplicate in a C1000 Touch Thermal Cycler (Bio-Rad, Hercules, CA, USA) using the GoTaq qPCR Master Mix (Promega, Madison, WI, USA). Each reaction was composed of $1 \mu \mathrm{L}$ of each primer $(10 \mu \mathrm{M}), 10 \mu \mathrm{L}$ of GoTaq Master Mix and $8 \mu \mathrm{L}$ of cDNA (diluted 1:40 or 1:100). The amplification conditions were $95^{\circ} \mathrm{C}$ for $5 \mathrm{~min}$ followed by 40 cycles of $95^{\circ} \mathrm{C}$ for $30 \mathrm{~s}$, and $60{ }^{\circ} \mathrm{C}$ for $60 \mathrm{~s}$. As reference genes $60 \mathrm{~S}$ ribosomal protein L23 (rpl23) and polyubiquitin B (ubi) were used for normalization of the data [34]. Amplification efficiency and specificity of each primer set were evaluated using standard and melting curves. The results were analyzed using qbase ${ }^{+}$software (Biogazelle, Zwijnaarde, Belgium). Reference gene stability was evaluated using the geNorm $M$ value and the coefficient of variation on the normalized relative quantities $(\mathrm{CV})$ values generated by the software. The thresholds for the $\mathrm{M}$ and $\mathrm{CV}$ values were set at 0.5 and 0.2 respectively for within-tissue comparisons and 1 and 0.5 for between-tissues comparisons [38]. An overview of the primers used in this work is given in Table 1. All primers were published [34] or designed using primer3 [39].

\subsection{RNA Iinterference (RNAi) Efficiency Experiments, RNAi Gene Expression Levels and Pre-Infection Experiments}

In order to test the effect of viral (IAPV or CrPV) presence on the RNAi efficiency, an assay was developed, containing three treatments. As a reporter gene, the endogenous ppia was chosen as it remains stable in the presence of IAPV [34]. Bumblebees belonging to the control group, with the purpose of determining the baseline ppia level, were injected with $5 \mu \mathrm{L}$ PBS and $24 \mathrm{~h}$ later with $20 \mu \mathrm{g}$ dsGFP (baseline control group) [36,40]. A second group was injected with $5 \mu \mathrm{L}$ PBS and $20 \mu \mathrm{g}$ dsPPIA and used to assess the RNAi efficiency in absence of the virus (RNAi control group). The virus treatment consisted of a first injection of $500 \mathrm{IAPV}$ or $10^{6} \mathrm{CrPV}$ particles, followed by an injection of $20 \mu \mathrm{g}$ dsPPIA (virus treatment group). Because of a slower replication of $\mathrm{CrPV}$ the time between virus infection and dsRNA treatment was extended to $48 \mathrm{~h}$ and not longer to limit the effect of a bumblebee age difference. This way, there is an equal time between the end of the experiment and the onset of death for both viruses. Each group consisted of 7-9 individuals (n). Within one group, all bumblebees were placed in the same microcolony. This institutes a potential problem of pseudoreplication, however, the stable climatic conditions and ad libitum feeding limit the risk of microcolony effects. Moreover, the chosen reporter gene ppia is very stable (tested over different ages, infection levels, and tissues), thus, any large effects are very unlikely to be the result of pseudoreplication. Brain, fat body, midgut and ovaries were dissected $48 \mathrm{~h}$ after dsRNA treatment and stored separately in $350 \mu \mathrm{L}$ RLT buffer. In order to assess the expression levels of the RNAi genes $24 \mathrm{~h}$ after IAPV treatment, a separate experiment was set up $(n=8-10)$. For the pre-infection experiments, similar timelines were used as in the RNAi efficiency assays. In a first experiment, injection with 500 particles of IAPV was followed by injection of $10^{6}$ particles of CrPV $24 \mathrm{~h}$ later $(n=9-10)$, in the other $10^{6}$ particles of $\mathrm{CrPV}$ were injected and $48 \mathrm{~h}$ later, 500 particles of IAPV $(n=11-15)$. Viral titers were analyzed using RT-qPCR $48 \mathrm{~h}$ after the second virus infection.

\subsection{Statistical Analysis}

All statistical analyses of RT-qPCR data were performed within SPSS (Version 23; IBM, Armonk, NY, USA). For experiments that evaluated viral titers, non-parametric methods were used (Friedman/Wilcoxon signed rank tests for dependent samples, Mann-Whitney $U$ tests for independent samples). In the functional RNAi assay and the evaluation of the RNAi gene levels, the data was $\log _{2}$ transformed as advised in [38] after which the data satisfied the normality and homoscedasticity assumptions for analysis of variance (ANOVA) and Student's $t$-test testing. 


\subsection{High Definition Mass Spectrometry (HDMSE)}

Fifteen bumblebees were injected with 500 IAPV particles and the ovaries were dissected after three days at standard rearing conditions. However, the workers were not given pollen as to limit the development of the ovaries. The ovaries were pooled per three individuals and crushed in liquid nitrogen. Two third of the resulting powder was stored at $-80{ }^{\circ} \mathrm{C}$ for mass spectrometry, while one third was dissolved in RLT buffer (RNeasy Mini Kit; Qiagen) awaiting RNA extraction (for confirmation of infection). The powdered sample was resuspended in an Eppendorf protein LoBind tube in $45 \mu \mathrm{L} 0.5 \mathrm{M}$ triethylammonium bicarbonate (TEABC; Sigma-Aldrich), supplemented with sodium dodecyl sulfate (SDS, $0.1 \% v / v)$ and acetonitrile (ACN; $10 \% v / v)$, in the presence of Halt Protease and Phosphatase Inhibitor Cocktail (Perbio Science, Erembodegem, Belgium) and $100 \mathrm{U}$ of benzonase nuclease (Sigma-Aldrich, St. Louis, MO, USA). The sample was sonicated on ice and centrifuged. The protein concentration was determined using the Bradford assay and $2.5 \mu \mathrm{g}$ of protein was reduced in $0.5 \mathrm{M}$ TEABC by adding $1 \mu \mathrm{L}$ reducing agent and incubating for $30 \mathrm{~min}$ at $60{ }^{\circ} \mathrm{C}$, followed by alkylation using a $10 \mathrm{mM}$ methyl methanethiosulfonate for $10 \mathrm{~min}$ at room temperature (RT). The samples were digested in $1 \mathrm{mM} \mathrm{CaCl} 2$ by adding trypsin/lysC (25:1 protein/enzyme ratio; Promega). They were placed overnight at $37^{\circ} \mathrm{C}$ and evaporated, after which the sample was resuspended in $0.1 \%$ formic acid (FA). $100 \mathrm{ng}$ of peptide sample, spiked with $25 \mathrm{fmol} \mathrm{Hi3}$ standard and $25 \mathrm{fmol} \mathrm{MSPD} \mathrm{standard,} \mathrm{was} \mathrm{injected} \mathrm{of} \mathrm{each} \mathrm{sample.}$

Peptides were analyzed using a nanoscale UPLC system (nanoAcquityUPLC, Waters Corporation, Milford, CT, USA) coupled to a Synapt G2-Si mass spectrometer (Waters Corporation). Peptides were first trapped on a $180 \mu \mathrm{m} \times 20 \mathrm{~mm}$ C18 Trap column in $0.1 \%$ FA and separation was performed on a HSS C18 $1.8 \mathrm{~m}, 100 \mathrm{~m} \times 250 \mathrm{~mm}$ analytical column at a flow rate of $300 \mathrm{~nL} / \mathrm{min}$ and a temperature of $45{ }^{\circ} \mathrm{C}$. A $0.1 \%$ formic acid with $4 \%$ dimethyl sulfoxide (DMSO) in water was used as mobile phase $\mathrm{A}$ and $80 \%$ ACN containing $0.1 \%$ formic acid as mobile phase B. Peptides were separated for $60 \mathrm{~min}$ at $1 \%-40 \%$ solvent B, for $1 \mathrm{~min} 40 \%-85 \%$ solvent B. After 7 min of rinsing using $85 \%$ solvent $B$ the column was re-equilibrated to the initial conditions. Eluted peptides were analyzed in positive mode ESI-MS using HDMS ${ }^{\mathrm{E}}$ with a collision energy look up table as described in [41] and the data were post acquisition lock mass corrected with [Glu1]-Fibrinopeptide B. The mass spectrometer was operating in $\mathrm{HDMS}^{\mathrm{E}}$ which couples high-efficiency ion mobility separations (IMS) with time of flight (TOF) mass analysis. The spectral acquisition time of a low and elevated energy scans was $0.6 \mathrm{~s}$ over an $\mathrm{m} / \mathrm{z}$ range of 50-2000.

Data analysis of the raw files obtained from the Synapt G2-Si was performed in Progenesis QI (Nonlinear Dynamics; Version 2.0). The PLGS Threshold Inspector was used to iterate through a range of apex low energy and high energy settings to determine the optimal threshold for protein identification. Peptides with charges from two to five were retained following the data normalization in the Progenesis. For protein identification, the LC-MS data were processed and searched by Protein Lynx Global SERVER (PLGS, Version 3.0.2; Waters Corporation) with peptide tolerance and fragment tolerance set to auto. Protein identifications were obtained by searching a compiled database of UniProtKB/Swiss-Prot entries belonging to IAPV supplemented with the cRAP database (laboratory proteins and dust/contact proteins) and sequences of spiked standard proteins, which was concatenated to a randomized decoy database. For peptide identification, the following search criteria were selected: (i) trypsin as digestion enzyme; (ii) up to one missed cleavage allowed; (iii) fixed methylthio-cysteine and variable methionine oxidation, deamidation at asparagine and glutamine. The false discovery rate (FDR) for protein identification in PLGS was set to 1\% threshold. Only proteins identified with at least two unique peptides were further considered.

\section{Results}

\subsection{Israeli Acute Paralysis Virus (IAPV) Genome Structure and HDMS ${ }^{E}$}

An overview of the genome structure of the Dicistroviridae IAPV and CrPV is given in Figure 1 and the $\mathrm{HDMS}^{\mathrm{E}}$ coverage is denoted by the darkness of the polyprotein sequences' background. 
The coverage differed between the (poly)proteins; the 64 detected peptides covered $50 \%$ of the AA sequence of the structural polyprotein (48 peptides), whereas only $12 \%$ of the non-structural protein was detected (16 peptides). Within the OrfX protein, none of the seven predicted peptides (at least 6 AA long) after trypsin digestion were detected. The presence of $1 \mathrm{~A}$ would be confirmed by detecting the Stop-Go translational cleavage at the NPG ${ }^{\mathbf{P}}$ site, but the resulting non-tryptic CGDWDSILLLLSGDIEENPG peptide was not observed.

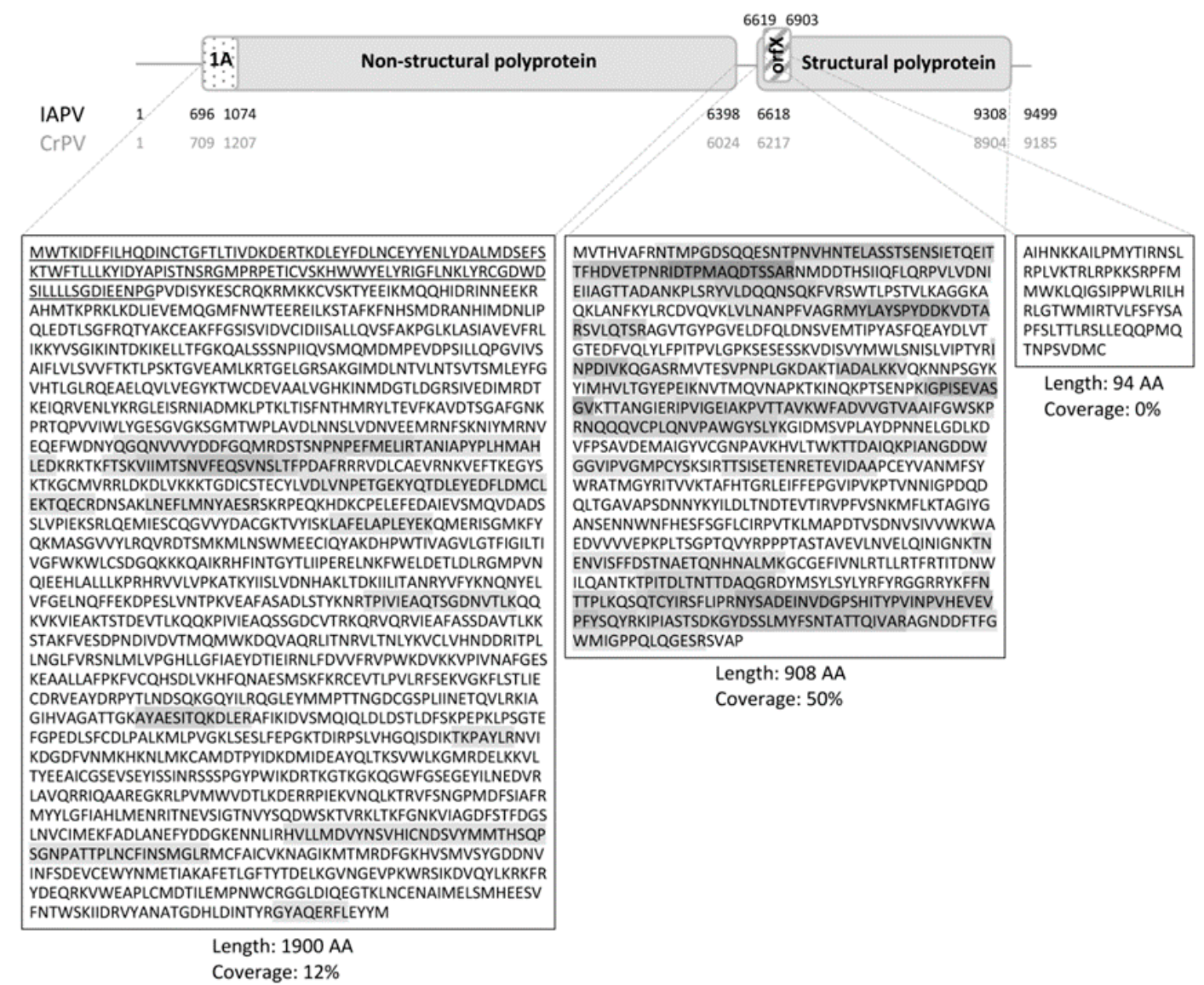

Figure 1. Israeli acute paralysis virus (IAPV) genome organization and high definition mass spectrometry $\left(\mathrm{HDMS}^{\mathrm{E}}\right.$ ) coverage. The Dicistroviridae genome consists of two open reading frames (ORFs), coding for a non-structural and a structural polyprotein. The first stretch of amino acids (AA) in the former polyprotein, upstream from Stop-Go translational cleavage site $\mathrm{NPG}^{\mathbf{V}} \mathrm{P}$, form the $1 \mathrm{~A}$ protein (dotted). In IAPV the length of this protein is $126 \mathrm{AA}$, whereas in cricket paralysis virus (CrPV) it is $166 \mathrm{AA}$. In the +1 frame of the $5^{\prime}$ end of the second ORF of IAPV, the possible orfX (striped) was predicted (not present in $\mathrm{CrPV}$ ). Start and stop nucleotide positions of the genome, the ORFs and the 1A and OrfX coding sequences are given in black for IAPV and grey for CrPV. (Poly)protein sequences are given and the location of the $1 \mathrm{~A}$ protein is underlined. $\mathrm{HDMS}^{\mathrm{E}}$ coverage is indicated by the darkness of the AA letter code's background. Polyprotein length and $\mathrm{HDMS}^{\mathrm{E}}$ coverage are given underneath the protein sequences.

\subsection{Virus Distribution in Bumblebee Tissues}

Infections with IAPV and CrPV showed a similar relative distribution over the tissues, with higher viral titers in the fat body and for IAPV also in the ovaria, and lower viral titers in brain and midgut (Figure 2). However, there was a remarkably large variation within the tissues. Interesting to note is that the average viral titer of IAPV in the fat body was around 1400 times the normalized level of the reference genes rpl23 and $u b i$, whereas for CrPV it was only 16 times, even with an infection 
dose of only 500 particles of IAPV and $10^{6}$ of CrPV. CrPV replication was confirmed by showing a 11,000 -fold increase in viral titers 4 days after infection compared to the input viral titer minutes after injection ( $n=5$ at each time point, data not shown).
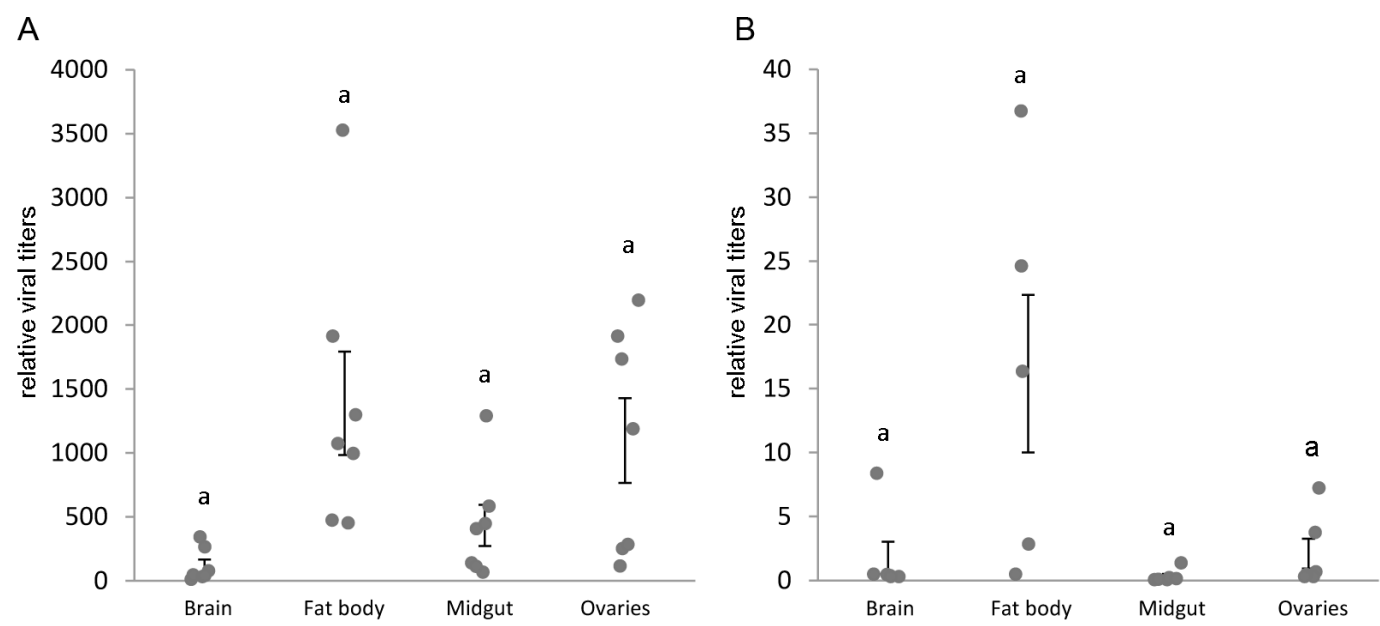

Figure 2. IAPV and CrPV tissue distribution in different bumblebee tissues. Seven bumblebees were injected with 500 particles of IAPV (A) or $10^{6}$ particles of $\mathrm{CrPV}(\mathbf{B})$ and the viral titers, after $72 \mathrm{~h}$ or $96 \mathrm{~h}$, respectively, were evaluated using RT-qPCR. The dots represent the individual viral titers, relative to the normalized level of the reference genes $r p l 23$ and $u b i$. The error bars show the SEM on the mean. Statistical analysis was performed using the non-parametric Friedman rank test as samples from the same individuals are not independent, resulting in significantly different viral titers over the tissues (IAPV: Q-stat. $=13.29, p=0.001 ; \mathrm{CrPV}$ : Q-stat. $=10.92, p=0.003$ ). Comparisons between treatments were made using Wilcoxon signed rank tests, none of which differed significantly on an $\alpha=0.05$ level after Bonferroni correction. In general, there was a considerably large variation within the tissues, but the higher viral titers were found in the fat body and ovaries for IAPV, and fat body for CrPV.

\subsection{RNAi Efficiency in Bumblebee Tissues}

In the ppia-targeting assays, the RNAi efficiency could be evaluated in both the absence and presence of the viruses. The expression levels of ppia in the RNAi control compared to the baseline control measure RNAi efficiency in a virus-free condition, whereas the levels in the virus treatment give an indication of how the virus influences the RNAi efficiency (Figure 3). In the 'IAPV' experiment, ANOVAs over the three treatments showed significant differences in ppia levels in the brain $\left(F_{2,22}=7.417, p=0.003\right)$, fat body $\left(F_{2,20}=29.317, p<0.001\right)$ and midgut $\left(F_{2,22}=11.218, p<0.001\right)$, but not in the ovaries $\left(F_{2,22}=0.788, n s\right)$. In the following sections, the ovaries will not be discussed further. The other tissues will collectively be referred to as 'responsive tissues'. For the 'CrPV' experiment, the ppia levels in the fat body were also statistically different $\left(F_{2,25}=5.864, p=0.008\right)$.

Different silencing efficiencies were observed between the selected bumblebee tissues after $48 \mathrm{~h}$ in the absence of viruses (comparison between baseline control and RNAi control in Figure 3). For both the IAPV and the CrPV experiment, the expression levels of ppia dropped significantly in the fat body (IAPV: $p=0.002$ (Tukey's HSD); CrPV: $p=0.011$ (Tukey's HSD)). However, the ppia levels dropped by $55 \%$ in the 'IAPV' experiment, whereas they only declined by $25 \%$ in the CrPV experiment (note that there can be no effect of virus presence in this comparison). In the brain and midgut, the ppia levels were slightly lowered, but there was too much biological variation in the IAPV experiment to confirm an RNAi event $\left(F_{2,22}=7.417, p>0.05\right.$ (Tukey's HSD) and $F_{2,22}=11.218$, $p>0.05$ (Tukey's HSD) respectively). 


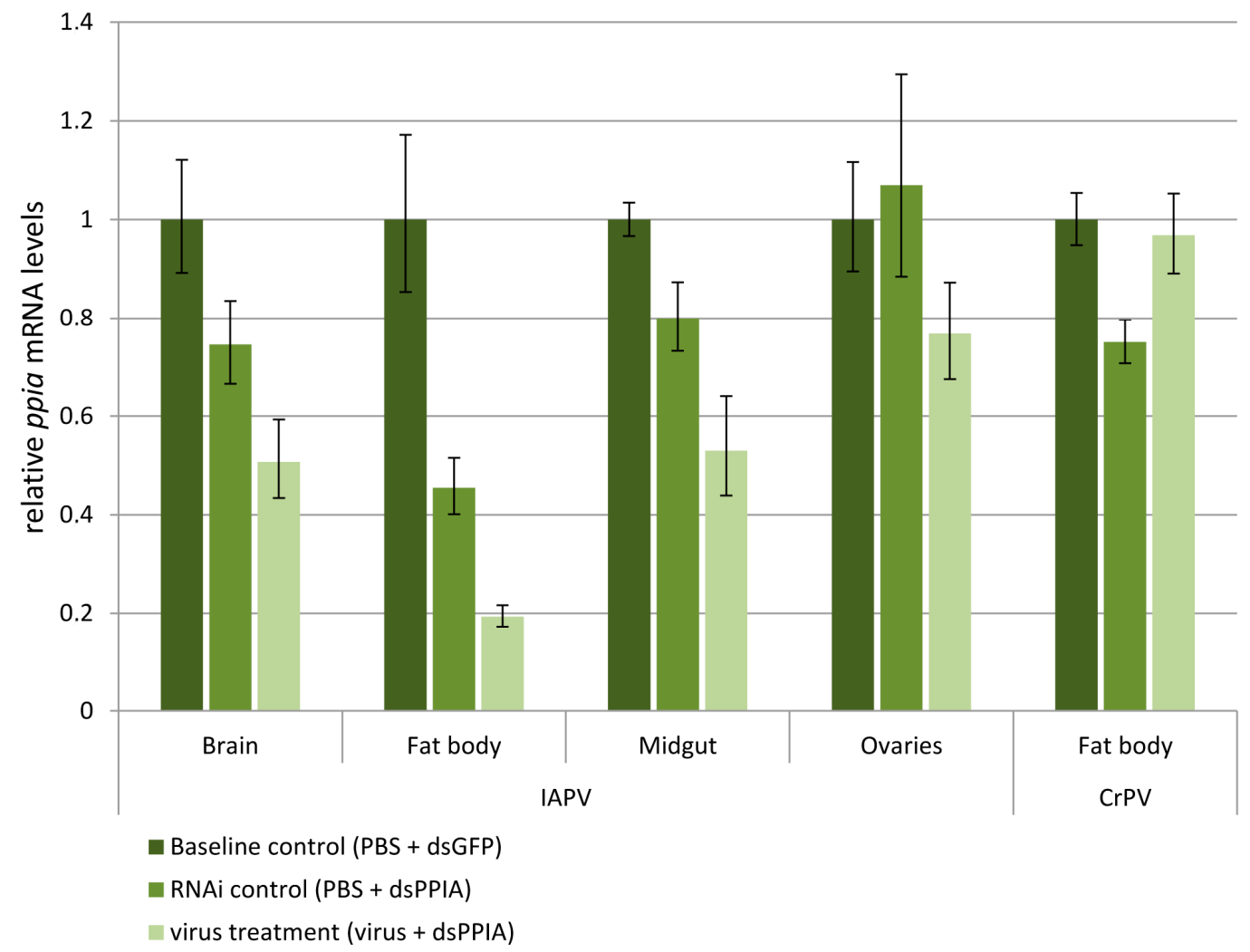

Figure 3. RNA interference (RNAi) efficiency in different bumblebee tissues, with and without IAPV or CrPV infection. Seven to nine bumblebees were treated with $20 \mu \mathrm{g}$ dsPPIA (or dsGFP in the baseline control). In the virus treatment 500 particles of IAPV or $10^{6}$ particles of $\mathrm{CrPV}$ were administered 24 or $48 \mathrm{~h}$, respectively, beforehand. The effect of the treatment on the silencing of the reporter gene ppia was evaluated using RT-qPCR $48 \mathrm{~h}$ after dsRNA application. All data was normalized to the ppia levels in the baseline control. Statistical analysis was performed using analysis of variance (ANOVA) on $\log _{2}$ transformed data with Tukey's HSD for post-hoc comparisons between the treatments. The columns represent the treatment mean \pm SEM (on a linear scale) and statistical differences on an $\alpha=0.05$ level are denoted by different letters above the column. Comparing the RNAi control (middle green) to the baseline control (dark green) represents the RNAi efficiency in the different tissues in the absence of viruses, with a significant RNAi event only happening in the fat body. IAPV virus treatment (light green) showed an increased silencing efficiency in brain, fat body and midgut, whereas CrPV treatment resulted in a diminished RNAi efficiency as the expression levels rise to a comparable level as in the baseline control.

\subsection{Virus Infection Alters RNAi Efficiency}

When IAPV was administered $24 \mathrm{~h}$ before the dsRNA treatment (virus treatment in Figure 3), a significant silencing effect on the reporter gene ppia was noticed in all three tissues of brain $(p=0.002$ (Tukey's HSD)), fat body $(p<0.001$ (Tukey's HSD)) and midgut $(p<0.001$ (Tukey's HSD)) compared to the baseline control, and in the case of the fat body and the midgut also a significant silencing compared to the RNAi control ( $p=0.001$ (Tukey's HSD) and $p=0.013$ (Tukey's HSD), respectively) The ppia levels in brain, fat body and midgut were lowered to $51 \%, 19 \%$ and $53 \%$ of their original levels, respectively. These results indicate an enhancement of the RNAi effect after IAPV infection in all tissues except for the unresponsive ovaries.

In the case of $\mathrm{CrPV}$, only the fat body was analyzed as it was the only tissue showing a significant silencing effect without IAPV presence, which is necessary for confirming RNAi inhibition. The virus was administered to the bumblebees $48 \mathrm{~h}$ before dsRNA treatment (instead of $24 \mathrm{~h}$ for IAPV). This later time-point was chosen because injection of $\mathrm{CrPV}$ resulted in slower replication and later onset of 
mortality of the bees. We have determined the onset of death to occur at 4 days post infection (dpi) and 5 dpi for IAPV and CrPV, respectively (data not shown), so this alteration promotes similar virus-host interactions at the moment of dsRNA treatment and RT-qPCR evaluation. Forty-eight hours after dsRNA treatment this resulted in a significant increase in ppia levels compared to the RNAi control ( $p=0.036$ (Tukey's HSD)). Moreover, no significant silencing could be observed compared to the baseline control ( $p>0.05$ (Tukey's HSD)), indicating that the RNAi system might have become impaired after $\mathrm{CrPV}$ infection.

\subsection{Expression Levels of Genes Involved in RNAi after Virus Infection}

In order to assess whether the altered RNAi efficiency after virus infection is due to an upregulation of the genes involved in the RNAi pathway, the expression levels of $d c r-2$, ago-2, ninaC, egghead and sid-1 were evaluated $24 \mathrm{~h}$ after IAPV infection (the moment the dsRNA is administered; virus injected compared to PBS injected; Figure $4 \mathrm{~A}$ ) and at the endpoint of the assay ( $72 \mathrm{~h}$ for IAPV and $96 \mathrm{~h}$ for $\mathrm{CrPV}$; virus treatment compared to RNAi control; Figure 4B).
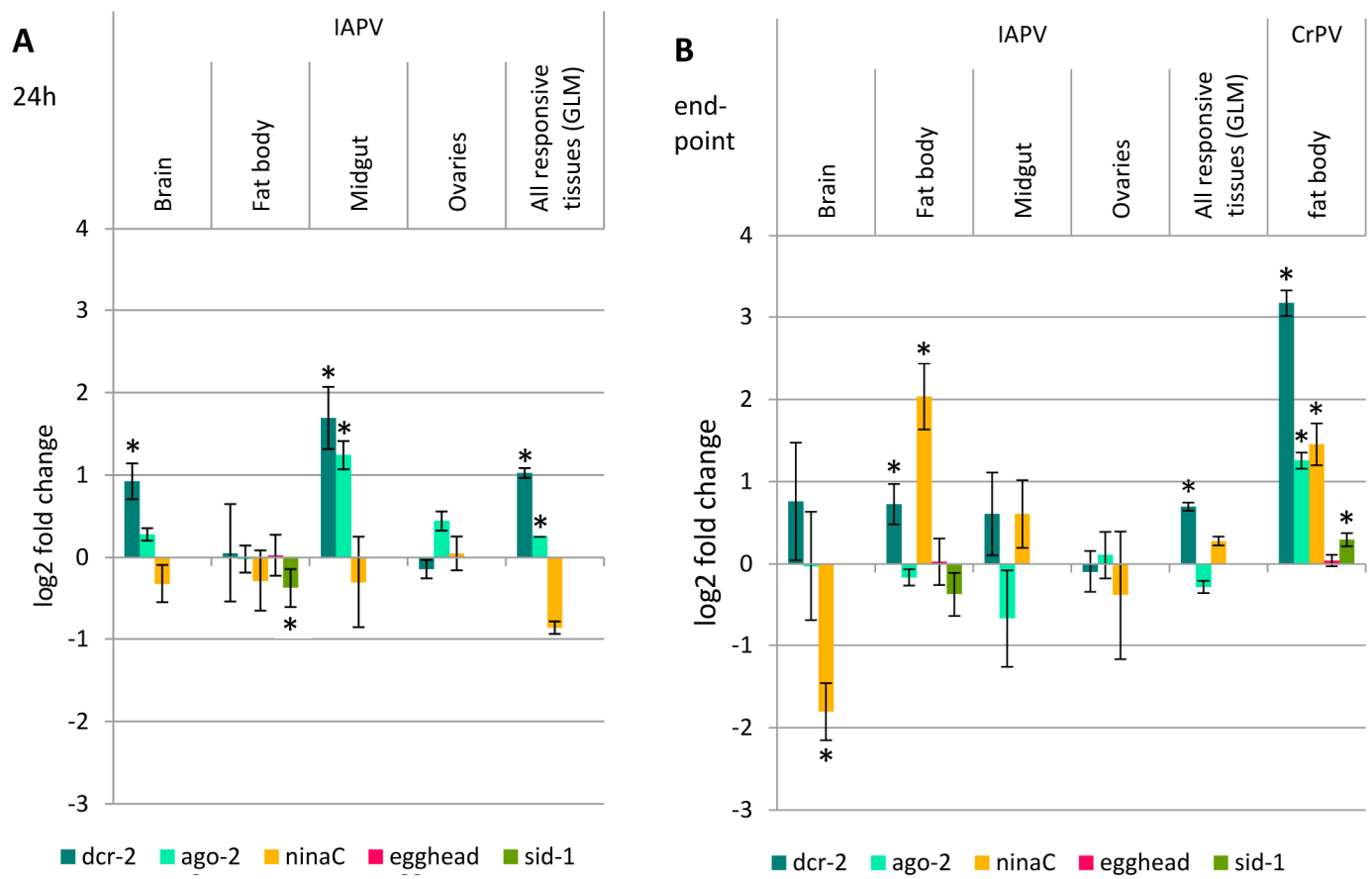

Figure 4. Fold change of selected RNAi genes upon IAPV or CrPV infection. The expression levels of the RNAi core genes $d c r-2$ and ago-2 and the systemic RNAi genes ninaC, egghead and sid-1 were evaluated at the moment of dsRNA application (A) and at the endpoint of the RNAi efficiency experiment (B) using RT-qPCR. Statistical analysis was performed using the Student's $t$-test on $\log _{2}$ transformed data. For the general linear model (GLM), only the responsive tissues, brain, fat body and midgut, were used. The columns represent the mean \pm SEM on a $\log _{2}$ scale, normalized to the control, and statistical differences on an $\alpha=0.05$ level are denoted by an asterisk. In the case of IAPV, dcr-2 showed a significant upregulation in some tissues at both 24 and $72 \mathrm{~h}$, and also over all responsive tissues. However, its fold change is considerably smaller than the nine-fold change of $d c r-2$ levels $96 \mathrm{~h}$ after CrPV infection. ago-2 expression levels were augmented in the midgut $24 \mathrm{~h}$ after IAPV infection and over all responsive tissues, but no effect was seen at the assay endpoint. For IAPV, the systemic RNAi genes showed occasional alterations in expression levels, however, over all responsive tissues the changes were not significant, whereas for $\mathrm{CrPV}$, nina $\mathrm{C}$ and sid-1 are significantly upregulated.

First, the RNAi core genes, $d c r-2$ and ago-2, were assessed in all tissues $24 \mathrm{~h}$ post IAPV infection (Figure 4A). A significant upregulation of $d c r-2$ was observed in the brain and midgut $\left(t_{9.334}=-2.572\right.$, 
$p=0.029 ; t_{8.497}=-2.275, p=0.05$, respectively). A general linear model (GLM) analysis over the responsive tissues showed a significant effect on $d c r-2$ over the different tissues $\left(F_{1}=5.638, p=0.021\right)$. The expression of ago- 2 was increased in midgut $\left(t_{17}=-4.432, p<0.001\right)$ and in the GLM $\left(F_{1}=6.356\right.$, $p=0.015$ ). At the endpoint of the assay (Figure 4B), a significant $d c r-2$ upregulation was detected in the fat body $\left(t_{14}=-2.314, p=0.036\right)$ and a similar, but more variable and not significant upregulation in the brain and midgut $\left(t_{7.68}=-0.996, p>0.05\right.$ and $t_{6.90}=-1.165, p>0.05$, respectively). The GLM over the responsive tissues showed a significant effect of $d c r-2\left(F_{1}=5.744, p=0.024\right)$. The expression levels of ago-2 remained unaltered in all tissues.

When looking at the systemic RNAi genes ninaC, egghead and sid-1 in the fat body, only the former was upregulated $\left(t_{14}=-4.23, p=0.001\right)$. Therefore, the expression levels of ninaC were also determined in the other tissues. However, ninaC was significantly downregulated in the brain $\left(t_{12.10}=2.775\right.$, $p=0.016)$ and no alteration was observed in the midgut $\left(t_{14}=-1.195, p>0.05\right)$ nor in the GLM over all responsive tissues $\left(F_{1}=0.715, \mathrm{~ns}\right)$.

For $\mathrm{CrPV}$, there was a much more evident upregulation of the RNAi core genes $d c r-2$ and ago-2 in the fat body after $96 \mathrm{~h}\left(t_{16}=-16.056, p<0.001\right.$ and $t_{16}=-10.706, p<0.001$, respectively $)$, as well as the systemic RNAi genes ninaC and sid-1 $\left(t_{16}=-2.978, p=0.009\right.$ and $t_{16}=-2.931, p=0.010$, respectively). The $d c r$-2 upregulation after CrPV infection is over nine-fold, whereas for IAPV over all responsive tissues not even two-fold. The expression levels of egghead remained unaltered $\left(t_{10.032}=-0.195\right.$, $p>0.05$ ) (Figure 4B).

\subsection{IAPV/CrPV Levels after Pre-Infection}

In both cases, there is a clear decrease in viral titers in the fat body compared to the control after pre-infection with the other virus. Pre-infection with CrPV for $48 \mathrm{~h}$ reduced the IAPV levels $90 \%$ (Mann-Whitney $\mathrm{U}=6, p<0.0001$, Figure 5A), whereas pre-infection with IAPV for $24 \mathrm{~h}$ reduced the CrPV levels with almost 99\% (Mann-Whitney $\mathrm{U}=2, p=0.0005$, Figure 5B). Lower IAPV levels in Figure $5 \mathrm{~A}$ are due to the evaluation occurring $48 \mathrm{~h}$ post-infection (pi), whereas in Figure 5B they are analyzed $72 \mathrm{~h}$ pi.

A

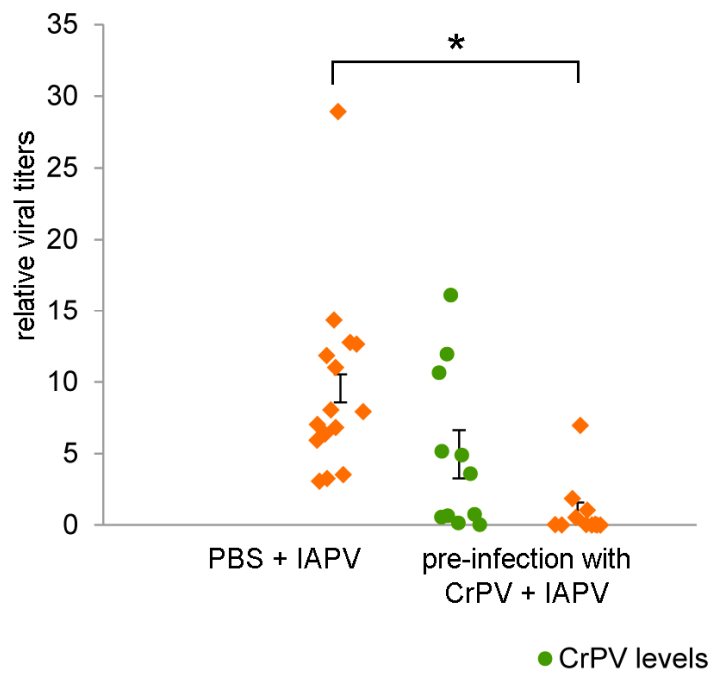

B

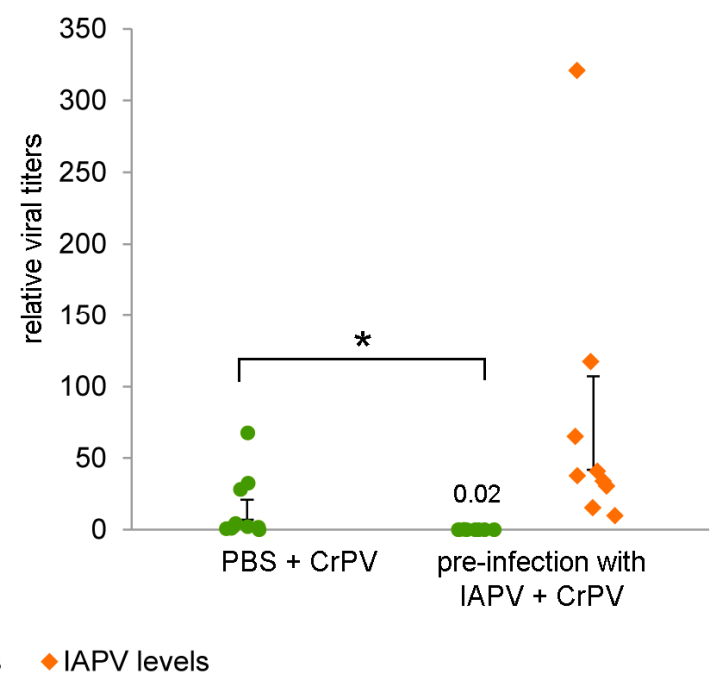

Figure 5. Virus levels of IAPV/CrPV after pre-infection with CrPV/IAPV. Bumblebees were either pre-infected with $10^{6}$ particles of CrPV and $48 \mathrm{~h}$ later with 500 particles of IAPV (A) or pre-infected with 500 particles of IAPV and $24 \mathrm{~h}$ later with $10^{6}$ particles of CrPV (B). The viral titers were analyzed $48 \mathrm{~h}$ after the second viral infection using RT-qPCR. The dots represent the individual data points relative to the normalized level of the reference genes $r p l 23$ and $u b i$, and the SEM of the mean is depicted by the error bars; ${ }^{*}$, relevant statistical differences on an $\alpha=0.05$ level (Mann-Whitney $U$ test). 


\section{Discussion}

Virus presence has been argued to be associated with variability of RNAi within a species as it can have a dual interaction with the RNAi defense system [42]. On one hand, the presence of viral dsRNA fragments activates the RNAi pathway, on the other hand, VSRs can inhibit this powerful antiviral defense system. The RNAi defense potency, in turn, influences viral replication and may determine the survival chances of the host. In this work, we examined whether the presence of an immunosuppressive virulence factor of IAPV can tip the scale towards one of these two opposites in the bumblebee.

A first confirmation of the presence of a VSR in IAPV could come on a proteomic level, from the detection of VSR-specific peptides. The ovaries were selected for $\mathrm{HDMS}^{\mathrm{E}}$ analysis because (1) the viral titers in the ovaries were considerably high; (2) protein extraction from the fat body is challenging; and (3) the ovaries do not contain complex microbiota like the midgut does, which might confound the analysis. The $\mathrm{HDMS}^{\mathrm{E}}$ on IAPV-infected ovaries resulted in a coverage that is comparable to a similar setup for IAPV in Apis mellifera [43] with a higher coverage for the structural polyprotein than the non-structural polyprotein. In order to confirm the presence of the 1A VSR, one specific peptide with the alternative Stop-Go translational cleavage [44] needed to be detected. This was not the case, but the lower presence of the corresponding polyprotein or peptide characteristics like the isoelectric point or peptide length could have impeded detection. The same reasons might also explain why no peptides belonging to the possible out-of-frame protein OrfX were found, but in this case, there are multiple peptides that theoretically should be detectable.

From the $\mathrm{HDMS}^{\mathrm{E}}$ result, by itself, it is not possible to confirm with any certainty the absence of these putative VSR proteins in IAPV-infected cells. However, when coupled with the RNAi efficiency data, where the presence of VSR in IAPV should suppress RNAi efficiency, it can be concluded that, even if the 1A or OrfX proteins are produced in the cell during IAPV infection, and even if they are functional VSRs, their functionality is being outweighed by the RNAi system or that the RNAi system of bumblebees is insensitive towards the VSRs of IAPV.

Not only could the predicted VSR of IAPV not suppress the RNAi efficiency in B. terrestris, but also an enhancement of the RNAi activity was observed. The fact that a diminished RNAi effect is seen using the same setup for CrPV ensures the efficacy of the ppia assay. An argument could be made that the difference between the experiments could be explained by the longer incubation of CrPV. We believe it was appropriate to extend the viral pre-infection duration because of the lower virulence of $\mathrm{CrPV}$ while a 24-h age difference between the bumblebees will probably not affect their capacity for RNAi. The more important question is determining how this IAPV-induced enhancement of RNAi activity can be explained.

A first explanation could be that virus infection causes the ppia levels to drop because of a disturbed cellular machinery. However, we collected ample evidence that this is not the case (Figure S1). Another reason could be that the upregulation of the RNAi core genes that is sometimes seen after viral infection in insects $[36,45,46]$ could make this pathway more potent. We noticed a slight $(\sim 2$-fold) upregulation of $d c r-2$ after IAPV infection in some tissues which also showed an increased RNAi efficiency. In contrast, for CrPV a notably larger upregulation ( 9-fold) was seen. It seems that this upregulation of $d c r-2$ does not determine the outcome of the RNAi pathway, possibly because the VSR 1A is acting on Ago-2, a component downstream of Dcr-2 [15]. Interestingly, we have previously shown that $d c r-2$ silencing does not diminish IAPV replication in bumblebees, possibly because of the too robust replication of IAPV [36]. Second, host response to IAPV infection could enhance the systemic properties of the RNAi system, facilitating the spread of the silencing signal and resulting in an increased silencing efficiency. This argument seems less adequate as for IAPV, nothing really stood out (except some changes in ninaC expression but they are variable over the different tissues). Again, for $\mathrm{CrPV}$, more significant positive fold changes are noticed (i.e., nina $\mathrm{C}$ and sid- 1 in the fat body). The fact that an upregulation of nina $\mathrm{C}$ was also seen in the fat body after IAPV treatment might indicate a role of the fat body in triggering a systemic RNAi response, but additional experiments are 
needed before any conclusions can be drawn on this. The exact mechanism behind the IAPV-induced RNAi efficiency remains inconclusive; possibly one or more genes that drive RNAi efficiency fell out of our selection or a yet unknown RNAi signal-spreading mechanism is activated by the presence of IAPV.

The viral influence on the RNAi machinery, a key immune response against viral infections, has great implications for host-virus dynamics. It is important to repeat that IAPV is a known pathogen of various pollinating hymenopterans [24,25], whereas CrPV has been detected once in honeybees [29] and appears to infect bumblebees, but seems to have a wide experimental host range outside of the pollinators $[27,28]$. Please note that $\mathrm{CrPV}$ identification in honeybees was based on serological tests available at the time and thus misidentification due to cross-reactivity with related viruses cannot be excluded. The tissue distribution pattern of the two viruses IAPV and CrPV is remarkably similar, both having the highest viral titers in fat body, and a considerably large variation between individuals. In mosquitoes, the fat body has been suggested to be the primary amplifying tissue for the positive ssRNA viruses West Nile virus [47] and Dengue virus [48], where it is thought to be the intermediate station between the primary infection in the midgut and the spreading towards the other tissues. Like others have noted before, this is remarkable as the fat body is also considered a particularly immunocapable tissue [49] and we have observed this to be a tissue exhibiting a significant RNAi response. Although IAPV induced the antiviral defense system, IAPV reached 100-fold higher viral titers starting from a 2000-fold lower injection dose. This could indicate that RNAi potency is not the primary determining factor in viral infectivity. Cell entry and manipulation of the host cell's protein synthesis or other immune pathways could be more decisive for explaining viral replication dynamics, especially since IAPV has adapted to infect bees, so it could have evolved mechanisms for evading the immune response other than the suppression of RNAi.

Our findings are also interesting in light of RNAi-therapeutics development and the use of RNAi as a research tool in functional genomics. The RNAi efficiency in the absence of a virus varies between the different tissues examined, with a significant silencing effect only occurring in the fat body and ovaries which are unresponsive. It is conceivable that the virus could evade the therapeutic in tissues which are insensitive to RNAi, such as the ovaries which showed relatively high viral titers in this study. Variations in RNAi efficiency over insect tissues have also been found in Anopheles gambiae with salivary glands that are refractory to conventional RNAi [50] and in many lepidopterans for which RNAi experiments are generally more successful in the hemocoel-surrounding tissues and less in the epidermal tissues (overview in [51]). An insensitivity to RNAi in the ovaria, as observed here, was also seen in Schistocerca gregaria [52] in the honeybee Apis mellifera after siRNA injection [53], and was attributed to a lack of dsRNA uptake in this tissue in Locusta migratoria [54]. It needs to be noted that the dsRNA was delivered by injection and had direct access to most tissues through the hemolymph, therefore bypassing the midgut barrier. The results also affirm the need for an evaluation at the tissue level instead of at the whole-body level in similar experiments as both viral titers and RNAi efficiency differ considerably between tissues.

An interesting question emerging from these results is the functionality of the CrPV $1 \mathrm{~A}$ in bumblebees, a hymenopteran species, which was previously shown to be active in the dipteran Drosophila [15]. Although there is a statistically significant reduction in RNAi efficiency, the fact that the RNAi effect in absence of the virus is not that large prevents confirming its functionality within the bumblebee. As a single bee host is often infected with multiple viruses, VSRs could have competitive or synergistic effects. Pre-infection with a VSR-coding virus, such as CrPV, could facilitate subsequent infection and colonization, while an infection of IAPV would make it more difficult for other viruses to co-infect as the RNAi system becomes more efficient. Carrillo-Tripp et al. showed that pre-treatment with CrPV-1A could induce cytopathogenic effects of Deformed wing virus, persistently present in the AmE-711 cell line [31]. Our results show a large reduction in viral titers after pre-infection with the other virus. In the case of IAPV pre-infection, this could be the result of a combination of an enhanced RNAi machinery and competition for the same host resources. IAPV, under normal circumstances, 
replicates extremely efficiently in bumblebees. For $\mathrm{CrPV}$, however, this similar reduction of IAPV titers suggest that the VSR functionality, which was dubious in the RNAi assays, is not relevant. The mere presence of $\mathrm{CrPV}$, and its saturation of the translational machinery, limits IAPV replication. It would be interesting to examine how this pre-infection with CrPV influences IAPV virulence in natural infections. In conclusion, we can state that there is a complex interaction between viruses and the RNAi defense mechanism of the insect host. Therefore, VSR functionality cannot be inferred from virus relatedness and needs to be taken into account when looking at virulence and multi-virus/multi-host dynamics.

Supplementary Materials: The following figure is available online at www.mdpi.com/1999-4915/8/12/334/s1, Figure S1: Additional experiments illustrating the fact that ppia levels remain stable after virus infection or dsRNA treatment.

Acknowledgments: The authors would like to thank Eric Jan (Department of Biochemistry and Molecular Biology, University of British Columbia, BC, Canada) and Dulce Cordeiro dos Santos (Department of Biology, KU Leuven, Belgium) for providing the initial CrPV inoculum used for virus production and Joachim de Miranda (Department of Ecology, Swedish University of Agricultural Sciences, Sweden) for the initial IAPV inoculum. This work was funded by Fonds Wetenschappelijk Onderzoek (Belgium; FWO G018715N and FWO G028013N) and Bijzonder Onderzoeksfonds (Ghent University; BOF12/DOC/295).

Author Contributions: K.C. and I.M. conceived and designed the experiments; K.C. performed the experiments and analyzed the data. M.D. aided in the design, implementation, analysis and reporting of the mass spectrometry part of this study. K.C. drafted the paper and it was revised by M.D., I.M. and G.S.

Conflicts of Interest: The authors declare no conflict of interest.

\section{References}

1. Nasir, A.; Forterre, P.; Kim, K.M.; Caetano-Anollés, G. The distribution and impact of viral lineages in domains of life. Front. Microbiol. 2014, 5, 194. [CrossRef] [PubMed]

2. Walsh, D.; Mohr, I. Viral subversion of the host protein synthesis machinery. Nat. Rev. Microbiol. 2011, 9, 860-875. [CrossRef] [PubMed]

3. Samuel, C.E. Antiviral actions of interferons. Clin. Microbiol. Rev. 2001, 14, 778-809. [CrossRef] [PubMed]

4. Maillard, P.V.; Ciaudo, C.; Marchais, A.; Li, Y.; Jay, F.; Ding, S.W.; Voinnet, O. Antiviral RNA interference in Mammalian cells. Science 2013, 342, 235-238. [CrossRef] [PubMed]

5. Li, Y.; Lu, J.; Han, Y.; Fan, X.; Ding, S.-W. RNA interference functions as an antiviral immunity mechanism in Mammals. Science 2013, 342, 231-234. [CrossRef] [PubMed]

6. Soosaar, J.L.M.; Burch-Smith, T.M.; Dinesh-Kumar, S.P. Mechanisms of plant resistance to viruses. Nat. Rev. Microbiol. 2005, 3, 789-798. [CrossRef] [PubMed]

7. Karlikow, M.; Goic, B.; Saleh, M.-C. RNAi and antiviral defense in Drosophila: Setting up a systemic immune response. Dev. Comp. Immunol. 2014, 42, 85-92. [CrossRef] [PubMed]

8. Van Mierlo, J.T.; van Cleef, K.W.R.; van Rij, R.P. Small silencing RNAs: Piecing together a viral genome. Cell Host Microbe 2010, 7, 87-89. [CrossRef] [PubMed]

9. Marques, J.T.; Wang, J.-P.; Wang, X.; de Oliveira, K.P.V.; Gao, C.; Aguiar, E.R.G.R.; Jafari, N.; Carthew, R.W. Functional specialization of the small interfering RNA pathway in response to virus infection. PLoS Pathog. 2013, 9, e1003579. [CrossRef]

10. Obbard, D.J.; Gordon, K.H.J.; Buck, A.H.; Jiggins, F.M. The evolution of RNAi as a defence against viruses and transposable elements. Philos. Trans. R. Soc. Lond. B Biol. Sci. 2009, 364, 99-115. [CrossRef] [PubMed]

11. Saleh, M.-C.; Tassetto, M.; van Rij, R.P.; Goic, B.; Gausson, V.; Berry, B.; Jacquier, C.; Antoniewski, C.; Andino, R. Antiviral immunity in Drosophila requires systemic RNA interference spread. Nature 2009, 458, 346-350. [CrossRef] [PubMed]

12. Burgyán, J.; Havelda, Z. Viral suppressors of RNA silencing. Trends Plant Sci. 2011, 16, 265-272. [CrossRef] [PubMed]

13. Li, H.W.; Li, W.X.; Ding, S.W. Induction and suppression of RNA silencing by an animal virus. Science 2002, 296, 1319-1321. [CrossRef] [PubMed] 
14. Van Rij, R.P.; Saleh, M.C.; Berry, B.; Foo, C.; Houk, A.; Antoniewski, C.; Andino, R. The RNA silencing endonuclease Argonaute 2 mediates specific antiviral immunity in Drosophila melanogaster. Genes Dev. 2006, 20, 2985-2995. [CrossRef] [PubMed]

15. Nayak, A.; Berry, B.; Tassetto, M.; Kunitomi, M.; Acevedo, A.; Deng, C.H.; Krutchinsky, A.; Gross, J.; Antoniewski, C.; Andino, R. Cricket paralysis virus antagonizes Argonaute 2 to modulate antiviral defense in Drosophila. Nat. Struct. Mol. Biol. 2010, 17, 547-554. [CrossRef] [PubMed]

16. Van Mierlo, J.T.; Bronkhorst, A.W.; Overheul, G.J.; Sadanandan, S.A.; Ekstrom, J.O.; Heestermans, M.; Hultmark, D.; Antoniewski, C.; van Rij, R.P. Convergent evolution of argonaute-2 slicer antagonism in two distinct insect RNA viruses. PLoS Pathog. 2012, 8, e1002872. [CrossRef] [PubMed]

17. Schnettler, E.; Sterken, M.G.; Leung, J.Y.; Metz, S.W.; Geertsema, C.; Goldbach, R.W.; Vlak, J.M.; Kohl, A.; Khromykh, A.A.; Pijlman, G.P. Noncoding flavivirus RNA displays RNA interference suppressor activity in insect and Mammalian cells. J. Virol. 2012, 86, 13486-13500. [CrossRef] [PubMed]

18. Van Cleef, K.W.R.; van Mierlo, J.T.; Miesen, P.; Overheul, G.J.; Fros, J.J.; Schuster, S.; Marklewitz, M.; Pijlman, G.P.; Junglen, S.; van Rij, R.P. Mosquito and Drosophila entomobirnaviruses suppress dsRNA- and siRNA-induced RNAi. Nucleic Acids Res. 2014, 42, 8732-8744. [CrossRef] [PubMed]

19. Chen, Y.P.; Pettis, J.S.; Corona, M.; Chen, W.P.; Li, C.J.; Spivak, M.; Visscher, P.K.; de Grandi-Hoffman, G.; Boncristiani, H.; Zhao, Y.; et al. Israeli acute paralysis virus: Epidemiology, pathogenesis and implications for honey bee health. PLoS Pathog. 2014, 10, e1004261. [CrossRef] [PubMed]

20. Sabath, N.; Price, N.; Graur, D. A potentially novel overlapping gene in the genomes of Israeli acute paralysis virus and its relatives. Virol. J. 2009, 6, 1-7. [CrossRef] [PubMed]

21. Firth, A.E.; Wang, Q.S.; Jan, E.; Atkins, J.F. Bioinformatic evidence for a stem-loop structure $5^{\prime}$-adjacent to the IGR-IRES and for an overlapping gene in the bee paralysis dicistroviruses. Virol. J. 2009, 6, 193. [CrossRef] [PubMed]

22. Ren, Q.; Wang, Q.S.; Firth, A.E.; Chan, M.M.; Gouw, J.W.; Guarna, M.M.; Foster, L.J.; Atkins, J.F.; Jan, E. Alternative reading frame selection mediated by a tRNA-like domain of an internal ribosome entry site. Proc. Natl. Acad. Sci. USA 2012, 109, E630-E639. [CrossRef] [PubMed]

23. Valles, S.M.; Sabath, N. No evidence for translation of pog, a predicted overlapping gene of Solenopsis invicta virus 1. Virus Genes 2012, 45, 84-89. [CrossRef] [PubMed]

24. Cox-Foster, D.L.; Conlan, S.; Holmes, E.C.; Palacios, G.; Evans, J.D.; Moran, N.A.; Quan, P.-L.; Briese, T.; Hornig, M.; Geiser, D.M.; et al. A Metagenomic survey of microbes in honey bee colony collapse disorder. Science 2007, 318, 283-287. [CrossRef] [PubMed]

25. Meeus, I.; de Miranda, J.R.; de Graaf, D.C.; Wäckers, F.; Smagghe, G. Effect of oral infection with Kashmir bee virus and Israeli acute paralysis virus on bumblebee (Bombus terrestris) reproductive success. J. Invertebr. Pathol. 2014, 121, 64-69. [CrossRef] [PubMed]

26. Maori, E.; Paldi, N.; Shafir, S.; Kalev, H.; Tsur, E.; Glick, E.; Sela, I. IAPV, a bee-affecting virus associated with Colony Collapse Disorder can be silenced by dsRNA ingestion. Insect Mol. Biol. 2009, 18, 55-60. [CrossRef] [PubMed]

27. Plus, N.; Croizier, G.; Reinganum, C.; Scotti, P.D. Cricket paralysis virus and Drosophila C virus: Serological analysis and comparison of capsid polypeptides and host range. J. Invertebr. Pathol. 1978, 31, $296-302$. [CrossRef]

28. Chao, Y.-C.; Young, S.Y., III; Kim, K.S. Characterization of a picornavirus isolated from Pseudoplusia includens (Lepidoptera: Noctuidae). J. Invertebr. Pathol. 1986, 47, 247-257. [CrossRef]

29. Anderson, D.L.; Gibbs, A.J. Inapparent virus infections and their interactions in Pupae of the Honey Bee (Apis mellifera Linnaeus) in Australia. J. Gen. Virol. 1988, 69, 1617-1625. [CrossRef]

30. Manley, R.; Boots, M.; Wilfert, L. Emerging viral disease risk to pollinating insects: Ecological, evolutionary and anthropogenic factors. J. Appl. Ecol. 2015, 52, 331-340. [CrossRef] [PubMed]

31. Carrillo-Tripp, J.; Dolezal, A.G.; Goblirsch, M.J.; Miller, W.A.; Toth, A.L.; Bonning, B.C. In vivo and in vitro infection dynamics of honey bee viruses. Sci. Rep. 2016, 6, 22265. [CrossRef] [PubMed]

32. Chen, Y.; Zhao, Y.; Hammond, J.; Hsu, H.T.; Evans, J.; Feldlaufer, M. Multiple virus infections in the honey bee and genome divergence of honey bee viruses. J. Invertebr. Pathol. 2004, 87, 84-93. [CrossRef] [PubMed]

33. Wu, Y.Y.; Jia, H.R.; Wang, Q.; Dai, P.L.; Diao, Q.Y.; Xu, S.F.; Wang, X.; Zhou, T. Multiple Virus Infections and the Characteristics of Chronic Bee Paralysis Virus in Diseased Honey Bees (Apis Mellifera L.) in China. J. Apic. Sci. 2015, 59, 95-106. [CrossRef] 
34. Niu, J.; Cappelle, K.; de Miranda, J.R.; Smagghe, G.; Meeus, I. Analysis of reference gene stability after Israeli acute paralysis virus infection in bumblebees Bombus terrestris. J. Invertebr. Pathol. 2014, 115, 76-79. [CrossRef] [PubMed]

35. Sguazza, G.H.; Reynaldi, F.J.; Galosi, C.M.; Pecoraro, M.R. Simultaneous detection of bee viruses by multiplex PCR. J. Virol. Methods 2013, 194, 102-106. [CrossRef] [PubMed]

36. Niu, J.; Smagghe, G.; de Coninck, D.I.M.; van Nieuwerburgh, F.; Deforce, D.; Meeus, I. In vivo study of Dicer-2-mediated immune response of the small interfering RNA pathway upon systemic infections of virulent and avirulent viruses in Bombus terrestris. Insect Biochem. Mol. Biol. 2016, 70, 127-137. [CrossRef] [PubMed]

37. Wu, Q.; Luo, Y.; Lu, R.; Lau, N.; Lai, E.C.; Li, W.X.; Ding, S.W. Virus discovery by deep sequencing and assembly of virus-derived small silencing RNAs. Proc. Natl. Acad. Sci. USA 2010, 107, 1606-1611. [CrossRef] [PubMed]

38. Hellemans, J.; Mortier, G.; de Paepe, A.; Speleman, F.; Vandesompele, J. qBase relative quantification framework and software for management and automated analysis of real-time quantitative PCR data. Genome Biol. 2007, 8, R19. [CrossRef] [PubMed]

39. Koressaar, T.; Remm, M. Enhancements and modifications of primer design program Primer3. Bioinformatics 2007, 23, 1289-1291. [CrossRef] [PubMed]

40. You, H.; Wan, H.; Li, J.; Jin, B.R. Molecular cloning and characterization of a short peptidoglycan recognition protein (PGRP-S) with antibacterial activity from the bumblebee Bombus ignitus. Dev. Comp. Immunol. 2010, 34, 977-985. [CrossRef] [PubMed]

41. Distler, U.; Kuharev, J.; Navarro, P.; Levin, Y.; Schild, H.; Tenzer, S. Drift time-specific collision energies enable deep-coverage data-independent acquisition proteomics. Nat. Methods 2014, 11, 167-170. [CrossRef] [PubMed]

42. Swevers, L.; Vanden Broeck, J.; Smagghe, G. The possible impact of persistent virus infection on the function of the RNAi machinery in insects: A hypothesis. Front. Physiol. 2013, 4, 319. [CrossRef] [PubMed]

43. Michaud, S.; Boncristiani, H.F.; Gouw, J.W.; Strand, M.K.; Pettis, J.; Rueppell, O.; Foster, L.J. Response of the honey bee (Apis mellifera) proteome to Israeli acute paralysis virus (IAPV) infection. Can. J. Zool. 2014, 93, 711-720. [CrossRef]

44. Wang, Y.; Brent, C.S.; Fennern, E.; Amdam, G.V. Gustatory perception and fat body energy metabolism are jointly affected by vitellogenin and juvenile hormone in honey bees. PLoS Genet. 2012, 8, e1002779. [CrossRef] [PubMed]

45. Xu, J.; Grant, G.; Sabin, L.R.; Gordesky-Gold, B.; Yasunaga, A.; Tudor, M.; Cherry, S. Transcriptional pausing controls a rapid antiviral innate immune response in Drosophila. Cell Host Microbe 2012, 12, 531-543. [CrossRef] [PubMed]

46. Galbraith, D.A.; Yang, X.; Niño, E.L.; Yi, S.; Grozinger, C. Parallel epigenomic and transcriptomic responses to viral infection in honey bees (Apis mellifera). PLoS Pathog. 2015, 11, e1004713. [CrossRef] [PubMed]

47. Girard, Y.A.; Klingler, K.A.; Higgs, S. West Nile virus dissemination and tissue tropisms in orally infected Culex pipiens quinquefasciatus. Vector Borne Zoonotic Dis. 2004, 4, 109-122. [CrossRef] [PubMed]

48. Salazar, M.I.; Richardson, J.H.; Sánchez-Vargas, I.; Olson, K.E.; Beaty, B.J. Dengue virus type 2: Replication and tropisms in orally infected Aedes aegypti mosquitoes. BMC Microbiol. 2007, 7, 1-13. [CrossRef] [PubMed]

49. Gillespie, J.P.; Kanost, M.R.; Trenczek, T. Biological mediators of insect immunity. Annu. Rev. Entomol. 1997, 42, 611-643. [CrossRef] [PubMed]

50. Boisson, B.; Jacques, J.C.; Choumet, V.; Martin, E.; Xu, J.; Vernick, K.; Bourgouin, C. Gene silencing in mosquito salivary glands by RNAi. FEBS Lett. 2006, 580, 1988-1992. [CrossRef] [PubMed]

51. Terenius, O.; Papanicolaou, A.; Garbutt, J.S.; Eleftherianos, I.; Huvenne, H.; Kanginakudru, S.; Albrechtsen, M.; An, C.; Aymeric, J.L.; Barthel, A.; et al. RNA interference in Lepidoptera: An overview of successful and unsuccessful studies and implications for experimental design. J. Insect Physiol. 2011, 57, 231-245. [CrossRef] [PubMed]

52. Wynant, N.; Verlinden, H.; Breugelmans, B.; Simonet, G.; Vanden Broeck, J. Tissue-dependence and sensitivity of the systemic RNA interference response in the desert locust, Schistocerca gregaria. Insect Biochem. Mol. Biol. 2012, 42, 911-917. [CrossRef] [PubMed] 
53. Jarosch, A.; Moritz, R.F. Systemic RNA-interference in the honeybee Apis mellifera: Tissue dependent uptake of fluorescent siRNA after intra-abdominal application observed by laser-scanning microscopy. J. Insect Physiol. 2011, 57, 851-857. [CrossRef] [PubMed]

54. Ren, D.; Cai, Z.; Song, J.; Wu, Z.; Zhou, S. dsRNA uptake and persistence account for tissue-dependent susceptibility to RNA interference in the migratory locust. Locusta migratoria. Insect Mol. Biol. 2014, 23, 175-184. [CrossRef] [PubMed]

(C) 2016 by the authors; licensee MDPI, Basel, Switzerland. This article is an open access article distributed under the terms and conditions of the Creative Commons Attribution (CC-BY) license (http://creativecommons.org/licenses/by/4.0/). 